\title{
Synthesis of an E-BODIPY based fluorescent Co-polymer containing organoboron quinolate units
}

\author{
Priya Hewavitharanage, ${ }^{a}$, , Prince Nzeataa and Jeffrey Wiggins ${ }^{b}$ \\ a Department of Chemistry, University of Southern Indiana, Evansville, Indiana, 47712, USA \\ b School of Polymers and High Performance Materials, University of Southern Mississippi, Hattiesburg, Mississippi, 39406, USA \\ *Corresponding author at: Department of Chemistry, University of Southern Indiana, Evansville, Indiana, 47712, USA. \\ Tel.: +1.812.2285009; fax: +1.812.4651052. E-mail address: phewavitha@usi.edu (P. Hewavitharanage).
}

\section{ARTICLE INFORMATION}

Received: 08 October 2011

Received in revised form: 04 January 2012

Accepted: 04 January 2012

Online: 31 March 2012

\section{KEYWORDS}

\section{BODIPY}

Stokes shift

Fluorescence

Donor-acceptor

Energy transfer

Organoboron quinolate

\section{Introduction}

Four-coordinate boron compounds are interesting materials with attractive optoelectronic properties [1-6]. They have found various optoelectronic applications, such as materials for organic light-emitting diodes [1], sensors [7,8] and biological imaging [9]. Among all the four-coordinate boron compounds, BODIPY (4,4-difluoro-4-bora-3a-4a-diaza-sindacene) has received great attention due to its superior properties such as high fluorescent quantum yields, high absorption coefficients, and high photostability [10-12]. Its derivatives have found widespread application in modern science and medicine [10-13]. BODIPY derivatives have been used as acceptors and donors in energy transfer systems [10,14-19]. These systems have potential applications in dyesensitized solar cells [20,21], chemical sensors [22,23] and photodynamic therapy [24-26]. Recently, several groups have reported homo polymerization and copolymerization of BODIPY monomers to concentrate several chromophores into one molecule. However, the fluorescent quantum yields $(\Phi)$ of conjugated BODIPY polymers are often significantly low when compared to individual BODIPY chromophores [27-29].

Replacement of two fluorine atoms from boron of BODIPY (F-BODIPY) by other chromophores such as pyrene, anthracene, fluorene, etc., through ethynyl linking groups produces E-BODIPY molecules [19,30]. It is known that excitation of the attached chromophore transfers energy efficiently to the BODIPY core which then emits at a longer wavelength $[19,30]$. Chujo et al. synthesized an E-BODIPY monomer by replacement of the two fluorine atoms on the boron center of the F-BODIPY by 4-iodophenylacetylene to produce a polymerizable E-BODIPY fluorophore [31]. Copolymerization of the E-BODIPY fluorophore with diynes produced the fluorescent polymer in good yields [28].
According to our knowledge, this is the only report published on the synthesis of $E$-BODIPY based polymers. In these systems the BODIPY and the monomer units are not in conjugation, hence they act as two independent chromophores. Unlike in main chain conjugated BODIPY polymers, these E-BODIPY polymers fluoresce in high quantum yields [31].

Organoboron quinolates and their conjugated polymers have received significant attention due to their potential applications in organic light-emitting diodes (OLEDs) [1, 32,35]. In all known organoboron quinolate polymers, the quinolate ligand is the acceptor while the aromatic $\pi$ conjugated main chain is the donor [32-35]. Because quinolates absorb and emit at higher energy in comparison with BODIPY, we reasoned that a co-polymer of an organoboron quinolate and $E$-BODIPY would produce a new polymer where quinolate is the donor and the E-BODIPY is the acceptor. Surprisingly, to the best of our knowledge, synthesis of quinolate-BODIPY donor-acceptor systems has not been reported.

In this report we describe the synthesis and properties of a novel fluorescent co-polymer, where the $E$-BODIPY 3 , acts as the acceptor and the unit formed from bis(4-iodophenyl)boron quinolate 4, acts as the donor. Because the emission spectrum of organoboron quinolate 4 overlaps significantly with the absorption spectrum of 3, efficient energy transfer from quinolate ligand to the BODIPY is expected.

\section{Experimental}

\subsection{Instrumentation}

Melting points were recorded on a Thermo Scientific melting point apparatus and are uncorrected. ${ }^{1} \mathrm{H}$ NMR (300 $\mathrm{MHz})$ and ${ }^{13} \mathrm{C}$ NMR $(75 \mathrm{MHz})$ spectra were recorded at room temperature on a $300 \mathrm{MHz}$ JEOL nuclear magnetic resonance 
spectrophotometer. Chemical shifts are reported in parts per million (ppm), in $\mathrm{CDCl}_{3}$, using TMS as the internal reference $(0.00) .{ }^{1} \mathrm{H}$ data are reported as follows: multiplicity $(\mathrm{s}=$ singlet, $\mathrm{d}=$ doublet, $\mathrm{t}=$ triplet, $\mathrm{q}=$ quartet, $\mathrm{m}=$ multiplet, $\mathrm{br}=$ broad). UV-visible spectra were recorded using a Varian Cary Bio 300 UV-Vis Spectrophotometer. Fluorescence spectra were recorded using a Horiba Jobin Yvon Fluoromax-4 spectrofluorometer. Quantum yields of $\mathbf{3}$ and the polymer $\mathbf{5}$ were measured using Rhodamine B as the reference $(\phi=65 \%$ in ethanol). Quantum yield of monomer $\mathbf{4}$ was measured using 9,10-diphenylanthacene as the reference $(\phi=90 \%$ in cyclohexane). Molecular weights $\left(\mathrm{M}_{\mathrm{n}}\right.$ and $\left.\mathrm{M}_{\mathrm{w}}\right)$ and polydispersity index (PDI) of polymers were determined using a GPC system consisting of Waters Alliance 2695 Separations Module, an on-line multi-angle laser light scattering (MALLS) Detector (MiniDAWN ${ }^{\mathrm{M}}$, Wyatt Technology, Inc.) fitted with a Gallium arsenide laser $(20 \mathrm{~mW})$ operating at $690 \mathrm{~nm}$, an interferometric refractometer (Optilab DSPTM, Wyatt Technology, Inc.) operating at $35^{\circ} \mathrm{C}$ and $690 \mathrm{~nm}$ and two mixed DPL gel (Polymer Laboratories, Inc.) GPC columns (pore size range $50-104 \AA, 5 \mu \mathrm{m}$ bead size) connected in series. Freshly distilled THF served as the mobile phase and was delivered at a flow rate of $1.0 \mathrm{~mL} / \mathrm{min}$. (sample concentrations $\sim 7.0 \mathrm{mg} / \mathrm{mL}$, and the injection volume $=100 \mu \mathrm{L}$ ). Detector signals were simultaneously recorded using ASTRA software (Wyatt Technology, Inc.). High resolution mass spectra of the new compounds were obtained at the Department of Chemistry, University of Illinois at Urbana-Champaign.

\subsection{Synthesis}

All the chemicals were used as received from Aldrich without further purification unless otherwise stated. THF and diethyl ether were distilled from sodium and benzophenone under nitrogen, methylene chloride was distilled from calcium hydride prior to use. Crude products were purified by column chromatography on silica gel. Bis(4-iodophenyl)boron quinolate (4) was synthesized by a literature procedure [32].

\subsubsection{Synthesis of 4,4-difluoro-8-nonyl-2,6-diethyl-1,3,5,7- tetramethyl-4-bora-3a,4a-diaza-s-indacen (1)}

To a stirred solution of 3-ethyl-2,4-dimethylpyrole (1.0 g, $8.1 \mathrm{mmol})$ dissolved in dry $\mathrm{CH}_{2} \mathrm{Cl}_{2}(40 \mathrm{~mL})$ was added decanoyl chloride $(1.2 \mathrm{~g}, 3.9 \mathrm{mmol})$ at room temperature. The mixture was stirred at $50{ }^{\circ} \mathrm{C}$ for $2 \mathrm{~h}$, after which $\mathrm{CH}_{2} \mathrm{Cl}_{2}$ was evaporated under vacuum. To the residue, toluene $(30 \mathrm{~mL})$ and $\mathrm{CH}_{2} \mathrm{Cl}_{2}(10$ $\mathrm{mL})$ were added under argon, then triethylamine $(2.6 \mathrm{~mL}, 18.6$ mmol) was added. The mixture was stirred at room temperature for $30 \mathrm{~min}$ and then boron trifluoride diethyl etherate $(4 \mathrm{~mL}, 31.56 \mathrm{mmol})$ was added. The mixture was refluxed at $50{ }^{\circ} \mathrm{C}$ for $2 \mathrm{~h}$, after which the organic volatiles were removed under vacuum. To the residue water was added and extracted with $\mathrm{CH}_{2} \mathrm{Cl}_{2}$. The organic layer was dried over $\mathrm{Na}_{2} \mathrm{SO}_{4}$ and the solvent removed under vacuum. The purified product was obtained as a dark orange solid ( $62 \%$ yield). M.p.: $77-78{ }^{\circ} \mathrm{C}$. ${ }^{1} \mathrm{H}$ NMR $\left(300 \mathrm{MHz}, \mathrm{CDCl}_{3}, \delta, \mathrm{ppm}\right): 2.96(\mathrm{t}, J=9.0 \mathrm{~Hz}, 2 \mathrm{H}), 2.48$ (s, 6H), 2.39 (q, $J=7.6 \mathrm{~Hz}, 4 \mathrm{H}), 2.32(\mathrm{~s}, 6 \mathrm{H}), 1.62(\mathrm{br} \mathrm{m}, 2 \mathrm{H})$, $1.48(\mathrm{br} \mathrm{m}, 2 \mathrm{H}), 1.27$ (br s, 10H), $1.04(\mathrm{t}, J=7.6 \mathrm{~Hz}, 6 \mathrm{H}), 0.87(\mathrm{t}$, $J=6.6 \mathrm{~Hz}, 3 \mathrm{H}) .{ }^{13} \mathrm{C}$ NMR $\left(75 \mathrm{MHz}, \mathrm{CDCl}_{3}, \delta, \mathrm{ppm}\right): 152.0,145.1$, 135.7, 132.6, 131.0, 31.9, 29.6, 29.5, 29.3, 28.7, 17.3, 15.0, 14.9, 13.4, 12.5. HRMS (ESI, $m / z$ ) calcd. for $\mathrm{C}_{26} \mathrm{H}_{42} \mathrm{BN}_{2} \mathrm{~F}_{2}[\mathrm{M}+\mathrm{H}]+$ : 431.3409, found: 431.3406 .

\subsubsection{Synthesis of 4,4-trimethylsilylethynyl-difluoro-8- nonyl-2,6-diethyl-1,3,5,7-tetramethyl-4-bora-3a,4a-diaza-s- indacene (2)}

Ethynyltrimethylsilane $(0.24 \mathrm{~mL}, 1.72 \mathrm{mmol})$ was transferred to a Schlenk flask that was previously charged with anhydrous diethyl ether $(15 \mathrm{~mL})$. The Schlenk flask was cooled to $-78{ }^{\circ} \mathrm{C}$ and then $n$-BuLi $(1.08 \mathrm{~mL}, 1.73 \mathrm{mmol})$ was added. The mixture was stirred at $-78^{\circ} \mathrm{C}$ for $1 \mathrm{~h}$ and at room temperature for $30 \mathrm{~min}$. The mixture was then transferred to a solution of 1 (338 $\mathrm{mg}, 0.78 \mathrm{mmol}$ ) in THF $(50 \mathrm{~mL}$ ) at room temperature. The mixture was stirred at room temperature for $30 \mathrm{~min}$., diluted with $\mathrm{CH}_{2} \mathrm{Cl}_{2}$, and washed with water. After evaporation of solvents the crude mixture was purified to yield an orange solid (52\% yield). M.p.: $120-122{ }^{\circ}$ C. ${ }^{1} \mathrm{H}$ NMR $\left(300 \mathrm{MHz}, \mathrm{CDCl}_{3}, \delta\right.$, ppm): $2.96(\mathrm{t}, J=9.0 \mathrm{~Hz}, 2 \mathrm{H}), 2.66(\mathrm{~s}, 6 \mathrm{H}), 2.42(\mathrm{q}, J=6.0 \mathrm{~Hz}$, $4 \mathrm{H}), 2.32(\mathrm{~s}, 6 \mathrm{H}), 1.62(\mathrm{br} \mathrm{m}, 2 \mathrm{H}), 1.47(\mathrm{br} \mathrm{m}, 2 \mathrm{H}), 1.26$ (br s, $10 \mathrm{H}), 1.08(\mathrm{t}, J=6.0 \mathrm{~Hz}, 6 \mathrm{H}), 0.88(\mathrm{t}, J=9.0 \mathrm{~Hz}, 3 \mathrm{H}), 0.08(\mathrm{~s}, 18$ H). ${ }^{13} \mathrm{C}$ NMR (75 MHz, $\mathrm{CDCl}_{3}, \delta$, ppm): 152.1, 144.6, 133.4, 132.5, 129.3, 31.9(d), 30.5, 29.6, 29.3, 28.7, 22.8, 17.6, 15.0, 14.2, 13.9, 13.6, 0.6. HRMS (ESI, $m / z$ ) calcd. for $\mathrm{C}_{36} \mathrm{H}_{60} \mathrm{BN}_{2} \mathrm{Si}_{2}[\mathrm{M}+\mathrm{H}]+$ : 587.4388 , found: 587.4378 .

\subsubsection{Synthesis of 4,4-ethynyl-difluoro-8-nonyl-2,6-diethyl- 1,3,5,7-tetramethyl-4-bora-3a,4a-diaza-s-indacene (3)}

Compound 2 (500 mg, $0.83 \mathrm{mmol}$ ) was dissolved in methanol $(10 \mathrm{~mL})$ and transferred to a mixture of $\mathrm{NaOH}(665.7$ $\mathrm{mg}, 16.64 \mathrm{mmol})$ and methanol $(20 \mathrm{~mL})$. The mixture was stirred at room temperature until complete consumption of starting material was observed by TLC. The mixture was diluted with $\mathrm{CH}_{2} \mathrm{Cl}_{2}$, washed with water, and dried over anhydrous $\mathrm{Na}_{2} \mathrm{SO}_{4}$. The solvent was evaporated and the residue was purified to yield an orange solid (76\% yield). M.p.: 74-76 ${ }^{\circ} \mathrm{C} .{ }^{1} \mathrm{H}$ NMR $\left(300 \mathrm{MHz}, \mathrm{CDCl}_{3}, \delta, \mathrm{ppm}\right): 2.98(\mathrm{t}, J=9.0 \mathrm{~Hz}, 2 \mathrm{H})$ $2.72(\mathrm{~s}, 6 \mathrm{H}), 2.43(\mathrm{q}, J=6.0 \mathrm{~Hz}, 4 \mathrm{H}), 2.34(\mathrm{~s}, 6 \mathrm{H}), 2.16(\mathrm{~s}, 2 \mathrm{H})$, $1.62(\mathrm{br} \mathrm{m}, 2 \mathrm{H}), 1.48(\mathrm{br} \mathrm{m}, 2 \mathrm{H}) 1.27(\mathrm{br} \mathrm{s}, 10 \mathrm{H}), 1.06(\mathrm{t}, J=6.0$ $\mathrm{Hz}, 6 \mathrm{H}), 0.88(\mathrm{t}, J=9.0 \mathrm{~Hz}, 3 \mathrm{H}), 0.08(\mathrm{~s}, 18 \mathrm{H}) .{ }^{13} \mathrm{C}$ NMR $(75 \mathrm{MHz}$, $\left.\mathrm{CDCl}_{3}, \delta, \mathrm{ppm}\right): 151.9,144.9,134.0,132.8,129.3,82.7,31.9(\mathrm{~d})$, 29.6, 29.5, 29.3, 28.7, 22.8, 17.6, 15.0, 14.2, 14.0, 13.6. HRMS (ESI, $m / z$ ) calcd. for $\mathrm{C}_{30} \mathrm{H}_{44} \mathrm{BN}_{2}[\mathrm{M}+\mathrm{H}]^{+}: 433.3598$, found: 433.3598.

\subsubsection{Synthesis of polymer 5}

To a Schlenk flask monomer 3 (100 $\mathrm{mg}, 0.022 \mathrm{mmol}$ ), monomer 4 (123.4 mg, $0.22 \mathrm{mmol}$ ), and freshly distilled THF (5 $\mathrm{mL}$ ) were added, followed by a solution of $\mathrm{Pd}\left(\mathrm{PPh}_{3}\right)_{4}(25.4 \mathrm{mg}$, $0.022 \mathrm{mmol}$ ), CuI (4.20 mg, $0.022 \mathrm{mmol})$, and THF (5 mL), previously prepared in a glove box, and $\mathrm{Et}_{3} \mathrm{~N}$ ( $4 \mathrm{~mL}$ ). The mixture was stirred at room temperature under argon for six days, the solvent was evaporated, and the residue was extracted with $\mathrm{CH}_{2} \mathrm{Cl}_{2}$, the extract dried over $\mathrm{Na}_{2} \mathrm{SO}_{4}$ and the solvent evaporated. The crude was dissolved in a small amount of $\mathrm{CH}_{2} \mathrm{Cl}_{2}$ and poured into a large excess of methanol to precipitate the polymer. The polymer was collected by vacuum filtration, dried under vacuum and it was obtained as a deep red solid in $34 \%$ yield. ${ }^{1} \mathrm{H}$ NMR $\left(300 \mathrm{MHz} \mathrm{CDCl}_{3}, \delta\right.$, ppm): 8.47 (m), 7.67-7.13 (b, m), 3.01 (b, s), 2.77 (b, s), 2.47-2.31 (b, m,), $1.57(b, s), 1.27(b, s), 1.06(t), 0.88(t)$. GPC (THF, polystyrene standard), $\quad M_{\mathrm{n}}: \quad 17,320 \mathrm{~g} / \mathrm{mol}, \quad M_{\mathrm{w}}: 101,200 \mathrm{~g} / \mathrm{mol}$, polydispersity: 5.85 .

\section{Results and discussion}

\subsection{Synthesis of compounds 1, 2, 3 and the polymer 5}

Compounds 1, 2, 3, 4, and the polymer $\mathbf{5}$ were synthesized as it is shown in Scheme 1. Compound $\mathbf{1}$ was treated with the ethynyl anion to yield exclusively $\mathbf{2}$, no monosubstituted compound was observed. The trimethylsilyl group of $\mathbf{2}$ was removed with $\mathrm{NaOH}$ to yield 3 as the major product and a small amount of the monodeprotected product was isolated $(11 \%)$ All the compounds were air stable. BODIPY compounds with ethynyl groups attached to positions 2 and 6 are unstable and highly reactive due to the extended conjugation. 


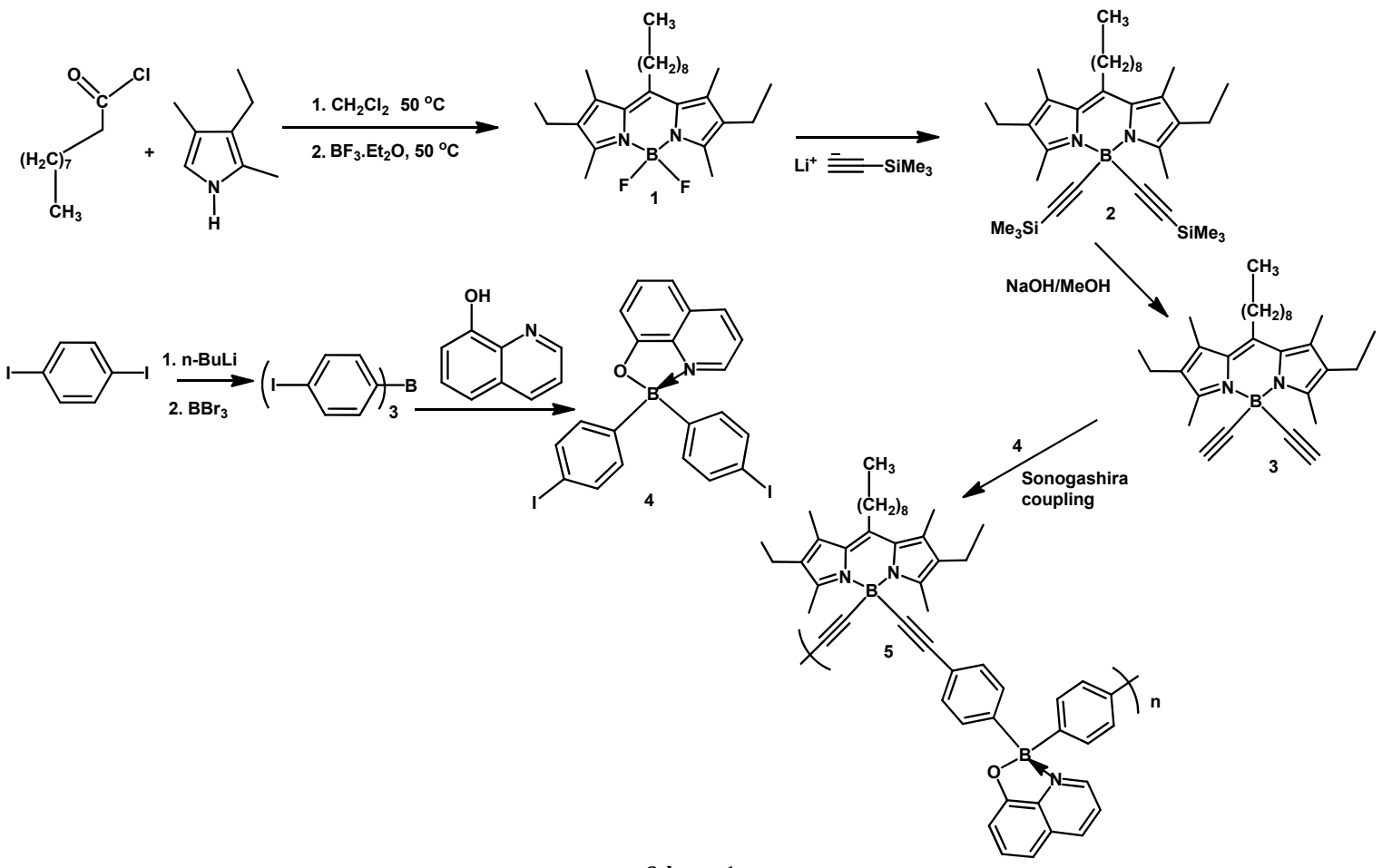

Scheme 1
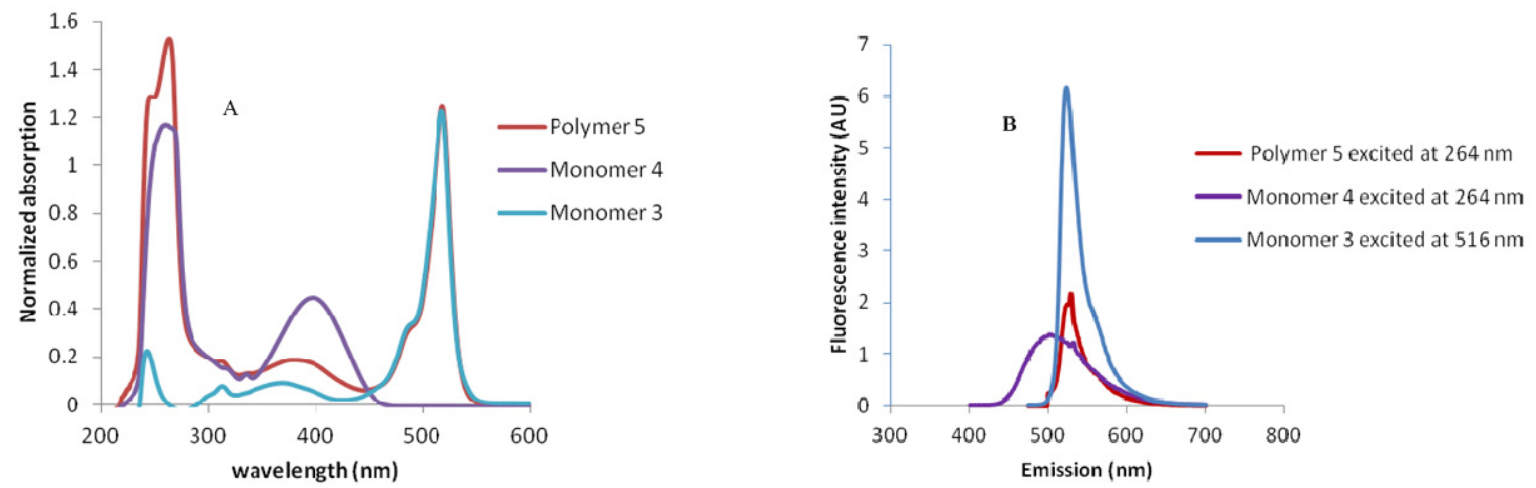

Figure 1. (A) Normalized absorption spectra of monomers 3, 4 and polymer 5 in THF $\left(1.0 \times 10^{-5} \mathrm{~mol} / \mathrm{L}\right)$ (B) Emission spectra of monomer 3 (excited at $516 \mathrm{~nm}$ monomer 4 (excited at $264 \mathrm{~nm}$ ) and polymer 5 (excited at $264 \mathrm{~nm}$ ).

However, the monomer 3 with two ethynyl groups at the boron center is stable, possibly due to the lack of conjugation between ethynyl groups and the BODIPY core. The polymer was synthesized by Sonogashira coupling of the BODIPY 3 with the quinolate $\mathbf{4}$ and isolated as a stable red solid.

\subsection{Photophysical properties}

The UV-Vis absorption and fluorescent experiments for monomers and the polymer were carried out in $\mathrm{CH}_{2} \mathrm{Cl}_{2}(1.0 \times$ $10^{-5} \mathrm{~mol} / \mathrm{L}$ ) using a Varian Cary Bio 300 UV-Vis Spectrophotometer. The bis(4-iodophenyl)boron quinolate (4) has a strong absorption at $264 \mathrm{~nm}$ and a weak absorption at $397 \mathrm{~nm}$ (Figure 1). The BODIPY derivatives 1, 2, and the BODIPY monomer 3 show strong absorptions $\sim 518 \mathrm{~nm}$, that is attributed to the $\mathrm{S}_{0}-\mathrm{S}_{1}\left(\pi-\pi^{*}\right)$ transition of the BODIPY moiety [36], while the weak band around $370 \mathrm{~nm}$ is attributed to the $\mathrm{S}_{0}-\mathrm{S}_{2}\left(\pi-\pi^{*}\right)$ transition [36]. No significant change in the absorption maximum of $\mathrm{S}_{0}-\mathrm{S}_{1}$ transition was observed in the polymer when it was compared with the absorption in the spectrum of monomer 3 (Figure 1, Table 1). This can be explained by the absence of $\pi$-conjugation along the polymer main chain due to the tetrahedral boron hybridization in the BODIPY moiety. However, the absorption band at $376 \mathrm{~nm}$ of the polymer $\mathbf{5}$ is a $9 \mathrm{~nm}$ red shift compared to the band corresponding to the $\mathrm{S}_{0}-\mathrm{S}_{2}$ transition of the monomer $\mathbf{3}$ and a $21 \mathrm{~nm}$ blue shift in comparison to the absorption peak at 397 $\mathrm{nm}$ of the quinolate monomer 4 (Table 1). Quantum yields of the monomer $\mathbf{3}$ and polymer $\mathbf{5}$ were measured in $\mathrm{CH}_{2} \mathrm{Cl}_{2}$ using Rhodamine B ( $\phi=65 \%$ in ethanol) as the reference [37] and 9,10-diphenylanthracene ( $\phi=90 \%$ in cyclohexane) [38] was used as the reference for quantum yields of monomer 4 Quantum yield of monomer 4 in $\mathrm{CH}_{2} \mathrm{Cl}_{2}$ was only $24 \%$. Chujo et al. [32] suggested that the low fluorescence quantum yield is due to the presence of two iodine atoms that quench fluorescence by heavy atom effect. 
Table 1. Photophysical properties of the monomers 3, 4 and the polymer 5 .

\begin{tabular}{llll}
\hline Compound & $\lambda_{\max }(\mathbf{n m})$ & $\lambda_{\text {em }}(\mathbf{n m})$ & Quantum yield (\%) \\
\hline 3 & 367,516 & 525 & $94^{\mathrm{a}}$ \\
4 & 264,397 & 489 & $24^{\mathrm{b}}$ \\
Polymer 5 & $264,376,516$ & 525 & $67^{\mathrm{a}}$ \\
\hline
\end{tabular}

a Rhodamine B was used as reference.

b 9,10-Diphenylanthacene was used as the reference.

The BODIPY monomer 3 emits at $525 \mathrm{~nm}$ with $94 \%$ quantum yield in $\mathrm{CH}_{2} \mathrm{Cl}_{2}$ (Table 1). Excitation of the BODIPY units of polymer 5 at $516 \mathrm{~nm}$ resulted in emission at $525 \mathrm{~nm}$ which is exactly the same as the emission of monomer 3 . The quantum yield was found to be $67 \%$. Excitation of the organoboron quinolate band of the polymer at $264 \mathrm{~nm}$ also resulted in emission at $525 \mathrm{~nm}$ corresponding to emission of BODIPY units of the polymer giving a $261 \mathrm{~nm}$ Stokes shift. Emission from the quinolate moiety was completely quenched (Figure 1b). The lack of quinolate emission and the origin of the large Stokes shift can be explained by the energy transfer from the organoboron quinolate unit to the BODIPY moiety $[14,19,30]$. Excitation of the peak at $376 \mathrm{~nm}$ can excite both quinolate and BODIPY chromophores but no emission through quinolate chromophores was observed. The visual colors of monomers 3, $\mathbf{4}$ and polymer $\mathbf{5}$ resulted from the exposition of their solutions at $254 \mathrm{~nm}$ using a hand held UV lamp is shown in Figure 2. The absence of emission from the BODIPY moiety in monomer $\mathbf{3}$ and its presence in the polymer $\mathbf{5}$ when they are excited by UV irradiation of $254 \mathrm{~nm}$ was consistent with the fluorescence data. The efficiency of energy transfer (EET) from quinolate when excited at $264 \mathrm{~nm}$ to the BODIPY unit was calculated using Equation 1 [14].

EET $=[1$-(fluorescence intensity of the donor in the polymer)/(fluorescence intensity of the free donor)]x 100

The energy transfer efficiency was found to be $99.6 \%$ which explains the efficient quenching of quinolate fluorescence. This novel donor-acceptor polymeric system shows superior properties such as high fluorescence quantum yield, high energy transfer efficiency and absorption in a wide spectral range, compared with other organoboron quinolate polymers [32-35]. The fluorescence quantum yield of the polymer is also higher than other BODIPY based conjugated polymers [10,27-29]. This system combines desirable properties of both BODIPY and quinolate ligand while preserving their original photophysical characteristics.

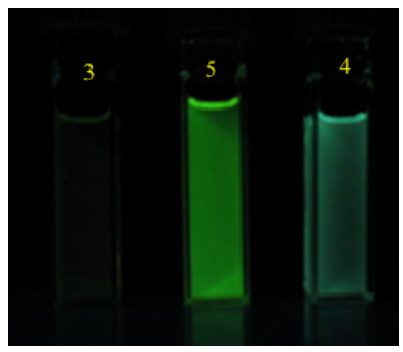

Figure 2. The visual colors of monomer 3, 4 and the polymer 5 when excited at $254 \mathrm{~nm}$ using a hand held UV lamp.

\section{Conclusions}

In conclusion, we have synthesized a novel donor-acceptor polymeric system with alternating 4,4'-ethynyl BODIPY and diphenylboron quinolate units. Upon UV irradiation the diphenylboron quinolate (the donor) transfers its energy efficiently to the BODIPY unit (acceptor), which then emits in the visible region giving a large virtual Stokes shift. Due to strong absorption in the UV region, efficient energy transfer and the high fluorescence quantum yield, the novel quinolate-
BODPY polymeric system may have potential applications in dye sensitized solar cells.

\section{Acknowledgements}

This work was supported by the Science and Engineering Research Grant Award of University of the Southern Indiana (Project No: 17228-01780), Faculty Research and Creative Work Award of the University of Southern Indiana (Project No: 17271-01780) and the Indiana Academy of Science (Project No. 25029-01820). Authors acknowledge reviewers for their invaluable comments on the manuscript.

\section{References}

[1]. Rao, Y. L.; Wang, S. Inorg. Chem. 2011, 50, 12263-12274.

[2]. Wang, S. Coord. Chem. Rev. 2001, 215, 79-98.

[3]. Entwistle, C. D.; Marder, T. B. Angew. Chem, Int. Ed. 2002, 41, 2927. 2931.

[4]. Entwistle, C. D.; Marder, T. B. Chem. Mater. 2004, 16, 4574-4585.

[5]. Qin, Y.; Kiburu, I.; Shah, S.; Jakle, F. Org. Lett. 2006, 8, 5227-5230.

[6]. Qin, Y.; Pagba, C.; Piotrowiak, P.; Jakle, F. J. Am. Chem. Soc. 2004, 126, 7015-7018.

[7]. Galbraith, E.; James, T. D. Chem. Soc. Rev. 2010, 39, 3831-3842.

[8]. Zhang, G.; Palmer, G. M.; Dewhirst, M. W.; Fraser, C. L. Nat. Mater. 2009, 8, 747-751.

[9]. Hapuarachchige, S.; Montano, G.; Ramesh, C.; Rodriguez, D.; Henson, L. H.; Williams, C. C.; Kadavakkollu, S.; Johnson, D. L.; Shuster, C. B. Arterburn, J. B. J. Am. Chem. Soc. 2011, 133, 6780-6790.

[10]. Benstead, M.; Mehl, G. L.; Boyle, R. W. Tetrahedron 2011, 67, 35733601.

[11]. Loudet, A.; Burgess, K. Chem. Rev. 2007, 107, 4891-4932.

[12]. Wood, T. E.; Thompson, A. Chem. Rev. 2007, 107, 1831-1861.

[13]. Haugland, R. P. The Handbook. A Guide to Fluorescent Probes and Labeling Technologies, $10^{\text {th }}$ ed., Molecular Probes, Inc., Eugene, Oregon, USA, 2005

[14]. Zhao, Y.; Zhang, Y.; Lv, X.; Liu. Y.; Chen, M.; Wang, P.; Liu, J.; Guo, W. J. Mater. Chem. 2011, 21, 13168-13171.

[15]. Ulrich, G.; Goeb, S.; De Nicola, A.; Retailleau, P.; Ziessel, R. J. Org. Chem. 2011, 76, 4489-4505.

[16]. Hablot, D.; Retailleau, P.; Ziessel, R. Chem. Eur. J. 2010, 16, 1334613351.

[17]. Ziessel, R.; Ulrich, G.; Olivier, J. H.; Bura, T.; Sutter, A. Chem. Comm. 2010, 46, 7978-7980.

[18]. Rachford, A. A.; Ziessel, R.; Bura, T.; Retailleau, P.; Castellano, F. N Inorg. Chem. 2010, 49, 3730-3736.

[19]. Goze, C.; Ulrich, G.; Ziessel, R. J. Org. Chem. 2007, 72, 313-322.

[20]. Warnan, J.; Buchet, F.; Pellegrin, Y.; Blart, E.; Odobel, F. Org. Lett. 2011 13, 3944-3947.

[21]. Kim, B.; Ma, B.; Donuru, V. R.; Liu, H.; Frechet, J. M. J. Chem. Comm 2010, 46, 4148-4150

[22]. McDonagh, C.; Burke, C. S; MacCraith, B. D. Chem. Rev. 2008, 108, 400422.

[23]. Fan, F. J.; Zhang, Y.; Murphy, C. B.; Angell, S. E.; Parker, M. F. L.; Flynn B. R.; Jones, W. E. Coord. Chem. Rev. 2009, 253, 401-422.

[24]. He, H.; Lo, P. C.; Yeung, S. L.; Fong, W. P.; Ng, D. K. P. Chem. Commun 2011, 47, 4748-4750.

[25]. Lim, S. H.; Thivierge, C.; Nowak-Sliwinska, P.; Han, J.; Van Den Bergh, H.; Wagniares, G.; Burgess, K.; Lee, H. B. J. Med. Chem. 2010, 53, 28652874.

[26]. Yogo, T.; Urano, Y.; Ishitsuka, Y.; Maniwa, F.; Nagano, T. J. Am. Chem. Soc. 2005, 127, 12162-12163.

[27]. Yoshii, R.; Nagai, A.; Chujo, Y. J. Polym. Sci, Part A: Polym. Chem. 2010, 48, 5348-5356.

[28]. Donuru, V. R.; Zhu, S.; Green, S.; Liu, H. Polymer 2010, 51, 5359-5368.

[29]. Donuru, V. R.; Vegesna, G. K.; Velayudham, S.; Green, S; Liu, H. Chem Mater. 2009, 21, 2130-2138.

[30]. Goze, C.; Ulrich, G.; Ziessel, R. Org. Lett. 2006, 8, 4445-4448.

[31]. Nagai, A.; Miyake, J.; Kokado, K.; Nagata, Y.; Chujo, Y. J. Am. Chem. Soc 2008, 130, 15276-15287.

[32]. Nagata, Y.; Chujo, Y. Macromolecules 2007, 40, 6-8

[33]. Nagata, Y.; Otaka, H.; Chujo, Y. Macromolecules 2008, 41, 737-740.

[34]. Tokoro, Y.; Nagai, A.; Kokado, K.; Chujo, Y. Macromolecules 2009, 42, 2988-2993.

[35]. Tokoro, Y.; Nagai, A.; Chujo, Y. Macromolecules 2010, 43, 6229-6233.

[36]. Toele, P.; Zhang, H.; Trieflinger, C.; Daub, J.; Glasbeek, M. Chem. Phys. Lett. 2003, 368, 66-75.

[37]. Casey, K. G.; Quitevis, E. L. J. Phys. Chem. 1998, 92, 6590-6594.

[38]. Hamai, S.; Hirayama, F. J. Phys. Chem. 1983, 87, 83-89. 